Journal of Clinical Investigation

Vol. 41, No. 9, 1962

\title{
CARDIOVASCULAR LESIONS AND CHANGES IN BLOOD COAGULATION AND FIBRINOLYSIS ASSOCIATED WITH DIET-INDUCED LIPEMIA IN THE RAT *
}

\author{
By SHAPUR NAIMI, ROBERT GOLDSTEIN, † MARTIN M. NOTHMAN, GEORGE F. \\ WILGRAM AND SAMUEL PROGER
}

(From the Pratt Clinic-New England Center Hospital and the Department of Medicine, Tufts University School of Medicine, Boston, Mass.)

(Submitted for publication March 26, 1962; accepted May 10, 1962)

Among the animals in which atherosclerosis has been experimentally induced, the rat has been the object of particular interest because of its omnivorous dietary habits (1). In 1956, Fillios, Andrus, Mann and Stare (2) reported induction of atherosclerosis in this animal, using a diet that included cholesterol, sodium cholate, and thiouracil. Yet in these and subsequent experiments by other investigators, vascular thrombosis, generally considered a secondary complication of atherosclerosis, was noticeably rare (3). In 1959, Hartroft, O'Neal and Thomas $(4,5)$ added large amounts of butter to the basic diet used by Fillios and co-workers and reported a high percentage of thrombosis and myocardial infarction. They especially noted that thrombotic lesions may develop without accompanying vascular changes, and they reported that a number of these thrombi were found in cardiac chambers. Many have questioned the significance of such lesions developed under severe experimental conditions. More recently, Gresham and Howard (6) reported confirmation of the experiments of Hartroft and associates. It appeared that these experiments might provide a suitable model to appraise the still controversial connection between lipemia and clotting changes in vitro as well as the relevance of all this to the mechanism of thrombosis in vivo.

* Supported by Research Grants H3753 (C3), H3649 (C2), and RG-9726 from the National Institutes of Health, Bethesda, Md., and a training grant from the National Heart Institute (HTS-5391). This work was presented in part at the meeting of the New England Cardiovascular Society, Boston, March 1961, and the 34th Scientific Sessions of the American Heart Association, Miami Beach, Fla., October 1961.

† Work done as an Established Investigator of the American Heart Association.

\section{MATERIALS AND METHODS}

Two sets of rats were used. Set A consisted of 80 male Wistar albinos divided into two comparable groups of 40 each. The average starting weight of both groups in this set was $319 \mathrm{~g}$. One group acted as chow-fed control throughout the experiment. The composition of the diet in the other group, from now on referred to as the experimental group, appears in Table I. All animals in set A were bled at monthly intervals for coagulation and lipid studies. In this set there was a high mortality among the animals of the experimental group. Set B consisted of 60 animals divided into two comparable groups of 30 each. In this set, in order to

TABLE I

Composition of the diet of the experimental group in percentage by weight

\begin{tabular}{lc}
\hline \multicolumn{1}{c}{ Ingredients } & $\begin{array}{c}\text { Percentage by } \\
\text { weight }\end{array}$ \\
\hline Cholesterol & 5.0 \\
Propylthiouracil & 0.3 \\
Sodium cholate & 2.0 \\
Casein * & 20.0 \\
Salt mix ture $\dagger$ & 4.0 \\
Vitamin mixture $\ddagger$ & 2.0 \\
Alphacel & 6.0 \\
Choline chloride & 0.2 \\
Sugar & 20.5 \\
Butter & 40.0 \\
\hline
\end{tabular}

* Casein (purified), Nutritional Biochemicals Corp.

† The salt mixture was the Wesson modification of the Osborne and Mendel salt mixture. The composition in per cent by weight is as follows: calcium carbonate 21.000; copper sulfate $\left(5 \mathrm{H}_{2} \mathrm{O}\right) 0.039$; ferric phosphate 1.470; manganous sulfate (anhyd.) 0.020 ; magnesium sulfate (anhyd.) 9.000; potassium aluminum sulfate 0.009 ; potassium chloride 12.000 ; potassium dihydrogen phosphate 31.000 ; potassium iodide 0.005 ; sodium chloride 10.500 ; sodium fluoride 0.057 ; tricalcium phosphate 14.900 .

$\ddagger$ Each kilogram of the vitamin mixture contained the following triturated in dextrose: Vitamin A concentrate $(200,000 \mathrm{U} / \mathrm{g}) 4.5 \mathrm{~g}$; vitamin D concentrate $(400,000 \mathrm{U} / \mathrm{g})$ $0.25 \mathrm{~g}$; alpha tocopherol $5.0 \mathrm{~g}$; ascorbic acid $45.0 \mathrm{~g}$; inositol $5.0 \mathrm{~g}$; choline chloride $75.0 \mathrm{~g}$; menadione $2.25 \mathrm{~g}$; $p$-aminobenzoic acid $5.0 \mathrm{~g}$; niacin $4.5 \mathrm{~g}$; riboflavin $1.0 \mathrm{~g}$; pyridoxine hydrochloride $1.0 \mathrm{~g}$; thiamine hydrochloride $1.0 \mathrm{~g}$; calcium pantothenate $3.0 \mathrm{~g}$; biotin $20 \mathrm{mg}$; folic acid $90 \mathrm{mg}$; vitamin $\mathrm{B}_{12} 1.35 \mathrm{mg}$. 
secure a longer life span and allow time for the development of pathological changes, the animals were not bled, since it was thought possible that the removal of relatively large volumes of blood for the studies was partly responsible for the high mortality in set $\mathrm{A}$. The average starting weight of the animals in set B was $294 \mathrm{~g}$ in the chow-fed control group and $315 \mathrm{~g}$ in the experimental group (the differences were not statistically significant). All animals were housed in individual cages and were fed ad lib.

\section{Pathological studies and methods}

Complete autopsies were done on all animals, but only heart, aorta, liver, and kidney were submitted to histological preparations. These organs were removed after death or sacrifice of the animals as quickly as possible and were fixed in 10 per cent calcium formalin. Hearts and aortae were then embedded in gelatin for the preparation of frozen sections. Each heart was cut with a razor blade into at least seven slices, each of which was used for two frozen sections. Thus, a minimum of 14 frozen sections, not more than $5 \mu$ thick, was prepared from each rat heart. This was done so that as few cardiac lesions as possible would be missed. The aortae were first stained in the gross and examined for lesions with a magnifying lens. They were then cut longitudinally on the freezing microtome, mounted, and searched for lesions under the microscope. The frozen sections were stained with oil red $\mathrm{O}$ in triethylphosphate. Livers and kidneys were embedded in paraffin and stained routinely with hematoxylin and eosin.

\section{Blood coagulation and lipid studies and methods}

Blood for coagulation and lipid studies was collected from both groups in set A simultaneously at monthly intervals. Rats were fasted for 16 hours before collection of the blood. Since a number of coagulation and lipid determinations required relatively substantial volumes of blood, it was not feasible to obtain enough blood from a single animal for all the studies. However, to randomize the possible errors from this source the same coagulation tests were done in the two groups at each venipuncture. Each rat was anesthetized with ether, and blood was drawn with a 21-gauge siliconized needle and syringe from the femoral vein, by a two-syringe technique. The volume of blood drawn at each venipuncture varied from 3 to $6 \mathrm{ml}$. Three per cent sodium citrate was used as the anticoagulant throughout, and 9 vol of blood was added to 1 vol of citrate. Blood was centrifuged at $2500 \mathrm{rpm}$ for 10 minutes.

\section{Coagulation methods}

Prothrombin time. The method of Quick was used except that a saline extract of acetone-dried human brain was used as a source of thromboplastin.

Stypven time. Stypven (Russell viper venom) was diluted 1:10,000 with distilled water, then diluted 1: 100,000 with 0.9 per cent saline. Platelet-poor plasma,
$0.1 \mathrm{ml}$, was incubated with $0.1 \mathrm{ml}$ of freshly prepared Stypven for 30 seconds at $37^{\circ} \mathrm{C}$; then $0.1 \mathrm{ml}$ of $0.02 \mathrm{M}$ calcium chloride was added and the clotting time determined.

Prothrombin levels. Plasma prothrombin was quantitatively determined by a modification of the Owren technique as described by Alexander (7).

Factor $V$ (labile factor). Activity was measured by determining the corrective effect on the prothrombin time of a substrate devoid of factor $\mathrm{V}$ but containing the other factors (prothrombin, factors VII and $\mathrm{X}$, and fibrinogen) that affect the prothrombin time (8).

Factors VII and $X$ activity. The procedure used was a modification of the Owren technique for determining proconvertin activity (9). This technique is now known to measure the combined activity of factors VII and X.

Factor $X$ activity. The method of Bachmann, Duckert and Koller (10) was used.

Thromboplastin generation. The test, as modified by Hicks and Pitney (11), for determining the thromboplastin generation from whole plasma was used. Inosithin (soyabean phospholipid) was added as a platelet substitute. This procedure measures the development of plasma or blood thromboplastin.

Fibrinolysis. The method described by Loomis (12) was used as modified by Scott and Thomas (13). Streptokinase was used to activate fibrinolysis. Rat plasma, $0.25 \mathrm{ml}$, was added to $0.05 \mathrm{ml}$ of a $1: 5$ dilution in saline of citrated human platelet-poor plasma. The mixture was incubated at $37^{\circ} \mathrm{C}$ for 30 seconds and then 0.1 $\mathrm{ml}$ of Varidase (Lederle Laboratory) containing $2000 \mathrm{U}$ of streptokinase per $\mathrm{ml}$ was added to the mixture. Thirty seconds after the reagents had been thoroughly mixed, $0.1 \mathrm{ml}$ of bovine thrombin (Upjohn) containing $50 \mathrm{U}$ per $\mathrm{ml}$ was added to the mixture and the stop watch was started. Thirty seconds later, at which time a clot had already formed, the open end of a capillary tube was inserted perpendicularly into the bottom of the clot. The tube was left undisturbed in a glass water bath at $37^{\circ} \mathrm{C}$. Once fibrinolysis had begun, the liquefied plasma ascended into the capillary tube. The end point was taken at the instant that the liquid level in the capillary tube reached the upper surface of the clot.

Platelet count. The method of Brecher and Cronkite (14) was used.

Plasma fibrinogen. The method of Ratnoff and Menzie as modified by Holburn (15) was employed.

Statistical studies. Comparison of the means was carried out by the $t$ test method (16).

\section{Chemical methods}

The serum cholesterol and cholesterol esters were determined by the method of Schoenheimer and Sperry (17). The lipid phosphorus was obtained by extracting the serum with the Bloor reagent and petroleum ether. The lipid phosphorus was converted to inorganic phosphorus by digestion and the inorganic phosphorus so obtained was measured by the procedure of Fiske and Subbarow (18). A factor of 25 was used to convert 
the lipid phosphorus to phospholipids. The total serum fatty acids were determined by the method of Stoddard and Drury (19). For the determination of ethanolamine phosphatide and serine phosphatide the method of Axelrod, Reichenthal and Brodie was used (20).

\section{RESULTS}

Course of the experiment. In the first four or five weeks of the experiment the animals on the diet lost weight. Thereafter, the weights became steady. Most of these animals showed varying degrees of hair loss as well as loss of hair luster. At death the experimental animals in set $\mathrm{A}$ had lost on the average $95 \mathrm{~g}$ in weight (range 35 to $150)$ and the experimental animals in set $B$ had lost an average of $115 \mathrm{~g}$ (range 90 to 210 ). The control animals, on the other hand, gained an average of $136 \mathrm{~g}$ (range 30 to 265) in set $\mathrm{A}$ and $165 \mathrm{~g}$ (range 40 to 260 ) in set $\mathrm{B}$ during a comparable interval.
TABLE II

The incidence of various cardiovascular-renal lesions in 19 experimental rats in set $A$ that came to autopsy after 100 days or more on the diet

\begin{tabular}{lc}
\hline \multicolumn{1}{c}{ Description of lesion } & $\begin{array}{c}\text { Incidence } \\
\text { of lesion }\end{array}$ \\
\hline $\begin{array}{c}\text { Atheromatous lesions in the } \\
\text { coronary arteries }\end{array}$ & 2 \\
$\begin{array}{c}\text { Thrombus-like masses in cardiac } \\
\text { chambers and great vessels } \\
\text { Total occlusion of coronary } \\
\text { artery due to thrombus-like } \\
\text { masses }\end{array}$ & 3 \\
Infarct in the heart & 1 \\
\hline
\end{tabular}

Pathological results. After about 100 experimental days there were definite pathological lesions. The incidence of various cardiovascular lesions in 19 experimental rats in set A and 26 in set $B$ that survived the diet for this period appears in Tables II and III respectively. The

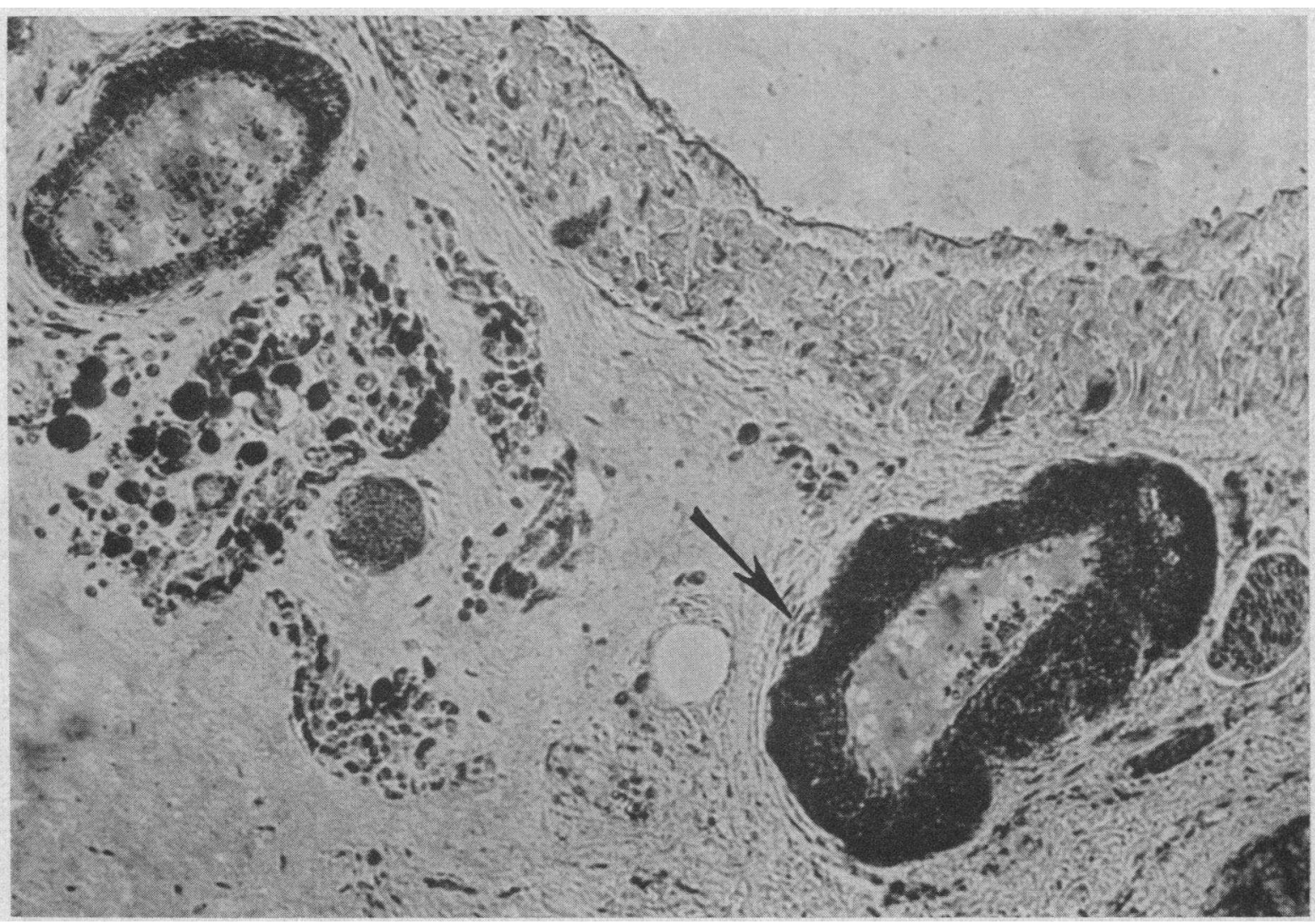

Fig. 1. Low-power, frozen section, oll Red o stain. A large branch of the coronary artery (arrow) near the sulcus coronarius shows signs of marked lipid infiltration of the arterial wall. There is also some increase in the width of the subintimal connective tissue layer which appears filled with lipid. This is indicative of an early atheromatous type of vascular lesion $(\times 60)$. 
TABLE III

The incidence of various cardiovascular-renal lesions in 26 experimental rats in set $B$ that came to autopsy after 100 or more days on the diet

\begin{tabular}{cc}
\hline \multicolumn{1}{c}{ Description of lesion } & $\begin{array}{c}\text { Incidence } \\
\text { of lesion }\end{array}$ \\
\hline $\begin{array}{c}\text { Atheromatous lesions in : } \\
\text { Coronary arteries } \\
\text { Aorta }\end{array}$ & 11 \\
Thrombus-like masses in cardiac \\
$\quad$ chambers and great vessels \\
Total or subtotal occlusion of \\
$\quad$ the coronary arteries due to: \\
$\begin{array}{l}\text { Atheromatous lesions } \\
\text { Thrombus-like masses }\end{array}$ \\
$\begin{array}{c}\text { Infarcts in: } \\
\text { Heart } \\
\text { Kidney }\end{array}$ \\
\hline
\end{tabular}

lesions were essentially similar in the two sets, but were more frequent and extensive in the experimental animals of set B. Experimental animals in this set survived on the diet for a longer period than did those of set $A$. The average length of survival of the experimental group animals in set $A$ was 78 days (range 29 to 153 ) and in set B 130 days (range 62 to 208). Since the lesions were more frequent in the experimental group of set $\mathrm{B}$, the numerical analysis in the following comments is based on the pathological lesions in this set; the descriptive remarks, on the other hand, apply equally to the experimental groups of both sets.

Lipomatous changes, consisting mostly of ex-

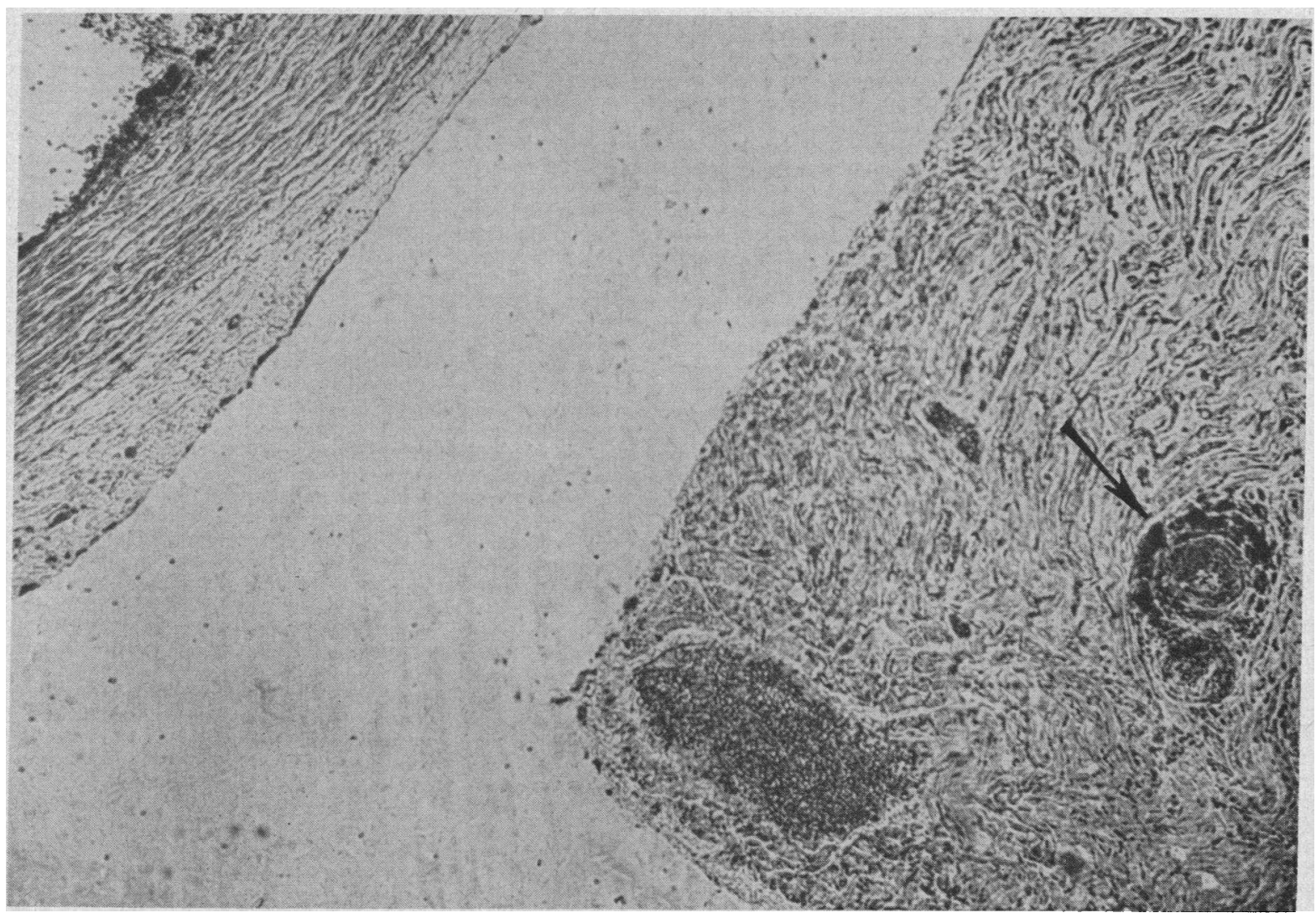

Fig. 2. Low-Power, FROzen SECtion, oIL RED o stain. On the left side of this photograph a small atheromatous plaque can be discerned in the intima of the ascending portion of the aorta. On the right side of the picture a larger branch of the coronary artery shows signs of subtotal occlusion (arrow). There is heavy lipomatous infiltration of the vessel wall accompanied by marked subintimal proliferation and lipid accumulation. Higher-power examination revealed that the lipid in the media and adventitia was intra- and extracellularly located, but in the subintimal space appeared predominantly as extracellular fat. The remaining lumen was large enough to accommodate a few erythrocytes only. Despite this decrease in the luminal diameter no thrombotic occlusion could be discerned in this or adjacent sections. Likewise, no morphological signs of myocardial infarction could be seen in any of the sections prepared from this animal $(\times 20)$. 


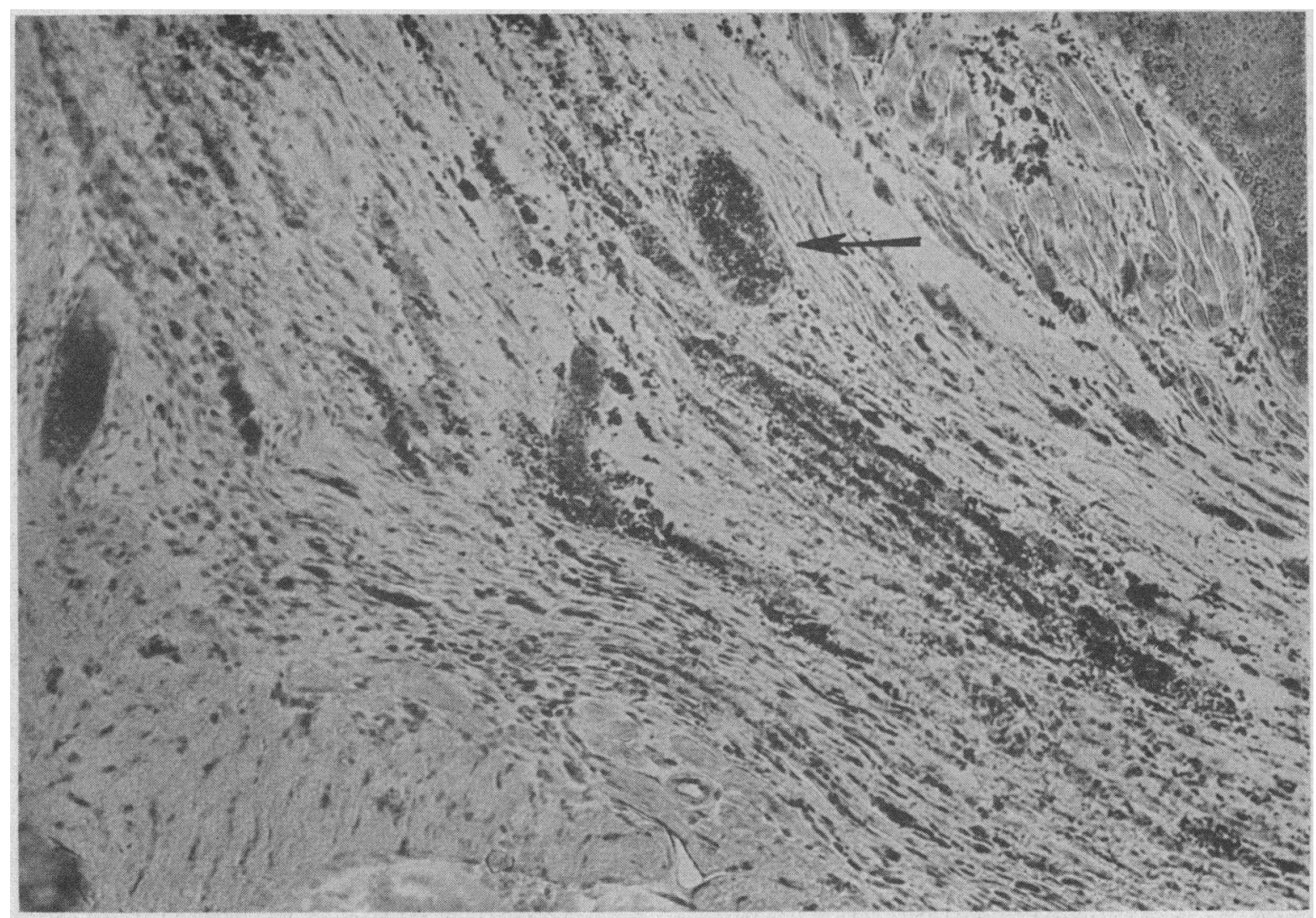

Fig. 3. MEdium-Power, frozen section, oil Red o stain. A myocardial infarct in the ventricular septum is characterized by disintegration of lipid-laden muscle fibers and macrophages filled with fat. To the left of the infarcted area, polymorphonuclear leukocytes are abundant. In the central portion of this micrograph a smaller branch of the coronary artery is subtotally occluded by atheromatous proliferation (arrow). The infarcted area is surrounded by myocardial tissue that appears normal in this section (uppermost and lowermost portion of the micrograph) $(\times 100)$.

tracellular lipid infiltrations of the coronary vessels and the cardiac valves without a proliferative response, were common. Atheromatous lesions in the coronary arteries, aorta, and the cardiac valves were frequent (Figure 1 ). Since the vascular wall of the rat normally shows very little subintimal connective tissue, it does not readily respond with cellular proliferation and increase in connective tissue ground substance. For this reason vascular lesions in these animals cannot be directly compared with human atherosclerosis. Nevertheless, many of these atheromatous arteries showed great thickening of the entire vessel wall, as well as narrowing of the lumen, sometimes leading to subtotal or total occlusion in the coronary arteries (Figure 2). Not infrequently subtotal or total coronary occlusions were found without an accompanying myocardial infarct.
Vascular narrowing was also sometimes due to accumulation of intravascular lipophages.

The myocardial infarcts were usually small and irregular in outline (Figure 3). They were characterized by degeneration of myocardial fibers which were clearly separated from the rest of the myocardium by a band of polymorphonuclear leukocytes. Thus, these infarcts were easily differentiated from areas of focal myocardial necrosis, which on occasions were found in animals dying from infectious processes.

On two occasions an occluded coronary artery was observed in the area adjacent to an infarct. In one case this occlusion was due to atheroma, and in the other to a thrombus-like mass. On three occasions. however, no coronary occlusions were seen in the vicinity of a myocardial infarct. It is believed that the serial sections were suf- 


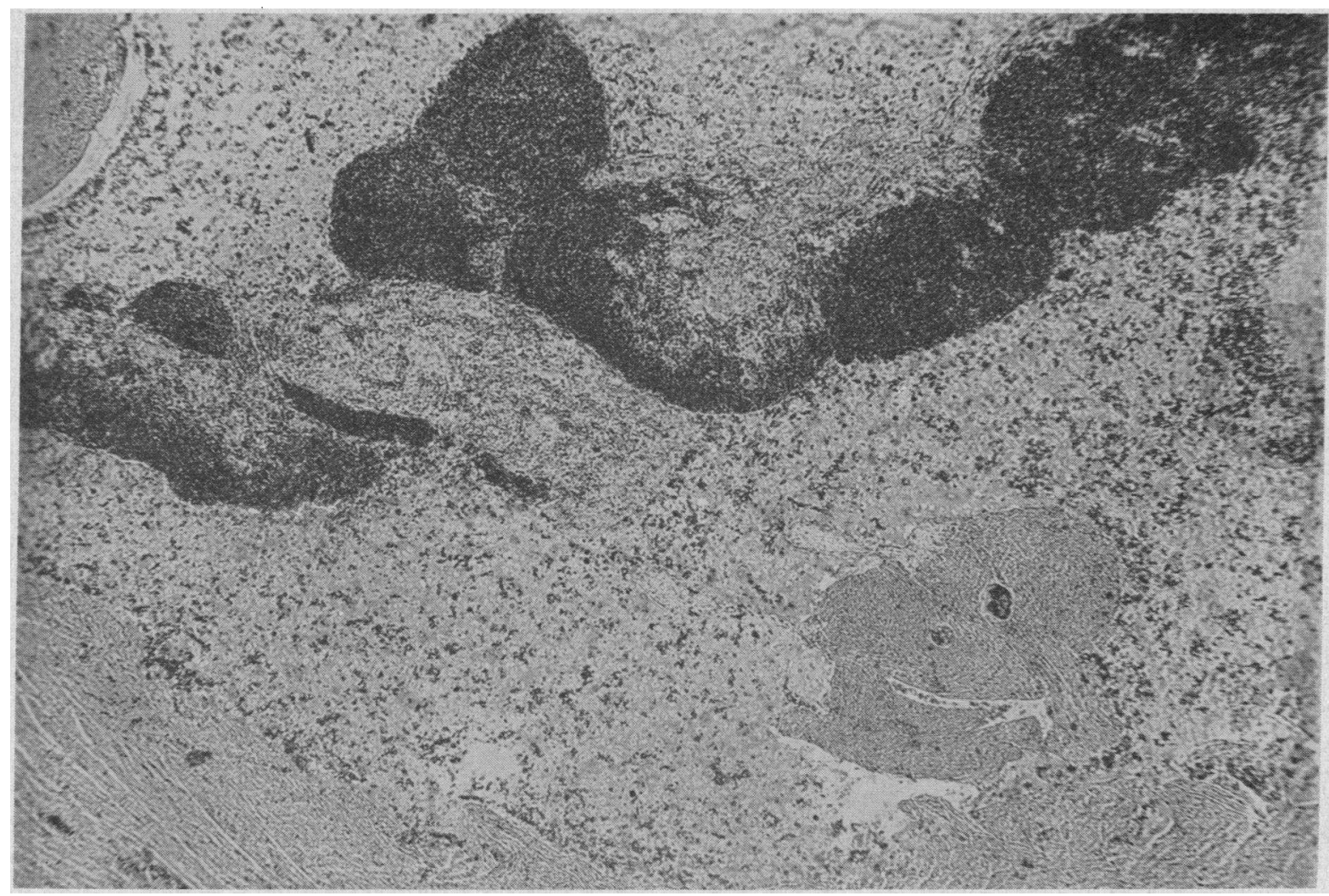

FIG. 4. LOW-POWER, FROzEN SECTION, oIL RED o STAIN. This micrograph shows the features of the thrombus-like mass, the nature of which remains undetermined. At the left lower corner the thrombus-like mass is adherent to a portion of the ventricular endocardium which appears intact in this particular section. The larger portion of this thrombus-like mass is composed of a broad band of trapped erythrocytes, seen as a black mass in the middle area of the micrograph. To both sides of this band of erythrocytes a fibrin-poor, platelet-poor, but lipid-rich material can be discerned. The sudanophilia of this thrombus-like mass is demonstrated in this frozen section by the gray background to both sides of the black center portion that represents erythrocytes stained with light green $(\times 30)$.

ficient to detect most, if not all, coronary occlusions and since in the majority of cases none was found, it is not clear whether there was a cause-and-effect relationship between the coronary lesions and the myocardial infarcts. Renal infarcts were large and could be detected in the gross. The lesions in the renal blood vessels resembled those described in the coronary arteries.

In the experimental group, large thrombus-like masses were commonly seen in the cardiac chambers and great vessels. On two occasions these thrombus-like masses were also present in the coronary arteries; these masses in the cardiac chambers were characterized by a high content of lipid and a relatively low content of fibrin, platelets, and leukocytes (Figure 4). Sometimes these large thrombus-like masses adhered to an apparently normal vascular endothelium or endocardium and, on rare occasions, to a lipomatous plaque. In most cases, however, no point of adherence of these masses to the vascular endothelium or endocardium was detected. The masses may have been sequellae to agonal clotting changes. It is of interest, however, that they were not observed in any animal of the control group, including those that died of an intercurrent infection.

In summary it may be stated that there was definite morphological evidence of coronary lesions, myocardial infarcts, and thrombus-like masses, but a cause-and-effect relationship among these three groups of lesions could not be ascertained.

All animals in the experimental group showed large. fatty livers. The lipid accumulation in the 
TABLE IV

The mean of blood lipid determinations at monthly intervals in the control and experimental groups*

\begin{tabular}{|c|c|c|c|c|c|c|}
\hline Groups & $\begin{array}{c}\text { Total } \\
\text { cholesterol }\end{array}$ & $\begin{array}{c}\text { Cholesterol } \\
\text { esters }\end{array}$ & $\begin{array}{c}\text { Total } \\
\text { fatty acids }\end{array}$ & $\begin{array}{l}\text { Ethanol- } \\
\text { amine phos- } \\
\text { phatide }\end{array}$ & $\begin{array}{c}\text { Serine } \\
\text { phosphatide }\end{array}$ & $\begin{array}{c}\text { Total } \\
\text { phospholipids }\end{array}$ \\
\hline Control & $m g / 100 m l$ & $\%$ & $m g / 100 \mathrm{ml}$ & $m g / 100 m l$ & $\mathrm{mg} / 100 \mathrm{ml}$ & $\mathrm{mg} / 100 \mathrm{ml}$ \\
\hline $\begin{array}{l}\text { Month } 1 \\
\text { Month } 2 \\
\text { Month } 3 \\
\text { Month } 5\end{array}$ & $\begin{array}{l}54.6 \quad(7) \\
64.0 \quad(4) \\
45.66(3) \\
58.5 \quad(2)\end{array}$ & $\begin{array}{l}83.3(7) \\
81.12(4) \\
82.66(3) \\
80.5 \quad(2)\end{array}$ & $\begin{array}{ll}269.0 & (4) \\
141.5 & (4) \\
190.0 & (3) \\
176.8 & (3)\end{array}$ & $\begin{array}{l}3.32(4) \\
3.94(4) \\
3.34(3) \\
3.73(3)\end{array}$ & $\begin{array}{l}5.76(3) \\
4.28(4) \\
5.05(3) \\
5.93(3)\end{array}$ & $\begin{array}{l}103.25(4) \\
129.25(4) \\
158.0(3) \\
113.2(3)\end{array}$ \\
\hline $\begin{array}{c}\text { Experimental } \\
\text { Month } 1 \\
\text { Month } 2 \\
\text { Month 3 } \\
\text { Month 5 }\end{array}$ & $\begin{aligned} 738.2 & (7) \\
1,187.0 & (4) \\
1,302.3 & (4) \\
1,270.0 & (3)\end{aligned}$ & $\begin{array}{ll}73.5 & (7) \\
65.4 & (4) \\
61.9 & (4) \\
56.0 & (3)\end{array}$ & $\begin{array}{l}1,173.25 \\
1,226.7 \\
2,716.2\end{array}$ & $\begin{array}{l}10.88(4) \\
19.82(4) \\
22.25(2) \\
28.91(4)\end{array}$ & $\begin{array}{l}17.5 \quad(4) \\
24.7(4) \\
28.06(2) \\
34.49(4)\end{array}$ & $\begin{array}{ll}485.75 & (4) \\
526.0 & (4) \\
684.0 & (2) \\
710.0 & (4)\end{array}$ \\
\hline
\end{tabular}

* The number of determinations on which each mean is based appears in parentheses.

liver had advanced to such an extent that it was not possible to determine whether it was predominantly of the periportal or pericentral type. Sometimes a periportal type of fibrosis was seen that was occasionally associated with nodular regeneration. In such cases a diagnosis of hepatic cirrhosis was made.

No cardiovascular lesions were encountered in the chow-fed control animals of either set throughout the course of these experiments.

Lipid results. The results of the lipid studies appear in Table IV. Each result is the average of all monthly determinations in a particular group. No studies were done during the fourth month since too frequent bleeding of the animals might interfere with the natural course of the experiment. It is clear from Table IV that in all the lipid determinations there was a marked difference between the normal controls and the experimental group. Cholesterol increased from an average normal level of around $50 \mathrm{mg}$ per $100 \mathrm{ml}$ to a level of over $1000 \mathrm{mg}$ per $100 \mathrm{ml}$ in the second month in the experimental group, an increase of about 20 -fold. There was not quite the

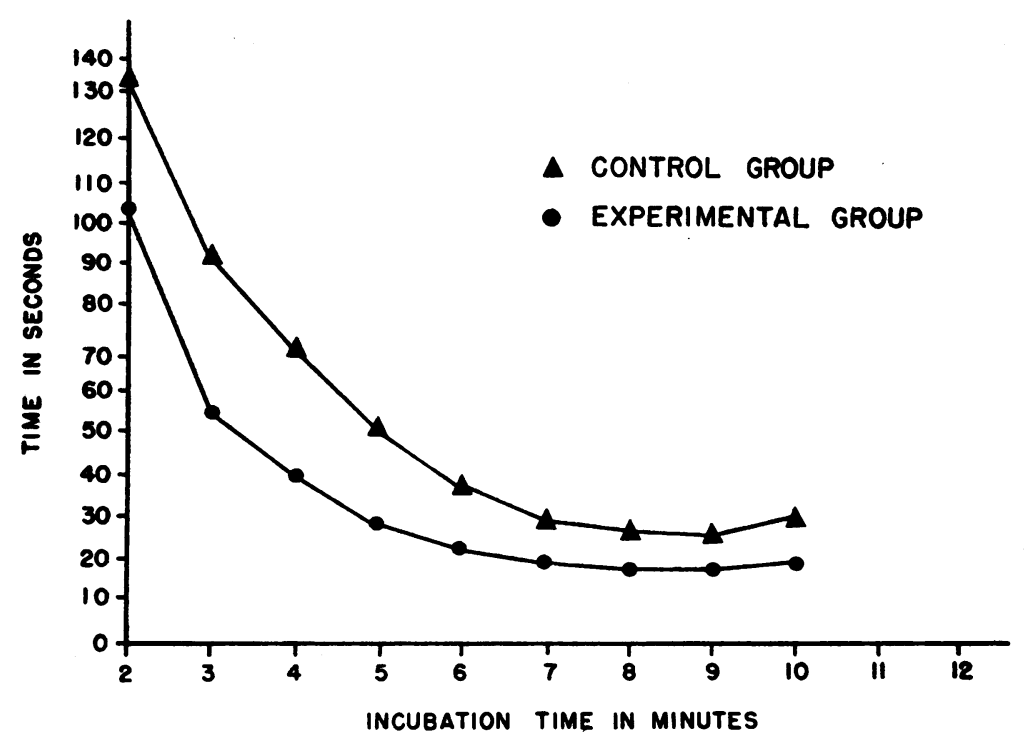

Fig. 5. Average CURVES of the Modified thromboplastin generation TEST AT THE END OF THE FIRST MONTH OF THE EXPERIMENT. Based on 10 determinations in each group. 
TABLE V

Mean of the Quick prothrombin and Stypven clotting times with their respective standard error of the mean at monthly intervals *

\begin{tabular}{|c|c|c|c|c|c|}
\hline & \multicolumn{2}{|c|}{$\begin{array}{l}\text { Quick prothrombin time } \\
\text { (in seconds) }\end{array}$} & & \multicolumn{2}{|c|}{$\begin{array}{l}\text { Stypven time (Russell viper } \\
\text { venom) (in seconds) }\end{array}$} \\
\hline & $\begin{array}{l}\text { Control } \\
\text { group }\end{array}$ & $\begin{array}{l}\text { Exp. } \\
\text { group }\end{array}$ & & $\begin{array}{l}\text { Control } \\
\text { group }\end{array}$ & $\begin{array}{l}\text { Exp. } \\
\text { group }\end{array}$ \\
\hline Month 1 & & & Month 1 & & \\
\hline $\begin{array}{c}\text { Mean } \\
\text { SEM } \\
\text { Month } 2\end{array}$ & $\begin{array}{r}15.1(11) \\
\pm 0.7\end{array}$ & $\begin{array}{r}13.5(11) \\
\pm 0.3\end{array}$ & $\begin{array}{c}\text { Mean } \\
\text { SEM } \\
\text { Month } 2\end{array}$ & $\begin{array}{r}25.4(11) \\
\pm 1.6\end{array}$ & $\begin{array}{r}17.8 \text { (11) } \\
\pm 1.4\end{array}$ \\
\hline $\begin{array}{c}\text { Mean } \\
\text { SEM } \\
\text { Month } 3\end{array}$ & $\begin{array}{r}19.3(10) \\
\pm 0.5\end{array}$ & $\begin{array}{r}15.9(10) \\
\pm 0.6\end{array}$ & $\begin{array}{c}\text { Mean } \\
\text { SEM } \\
\text { Month } 3\end{array}$ & $\begin{array}{r}38.4(5) \\
\pm 2.9\end{array}$ & $\begin{array}{l}30.8(5) \\
\pm 1.3\end{array}$ \\
\hline $\begin{array}{c}\text { Mean } \\
\text { SEM } \\
\text { Month } 5\end{array}$ & $\begin{array}{l}16.9(4) \\
\pm 0.8\end{array}$ & $\begin{array}{r}15.3(4) \\
\pm 0.8\end{array}$ & $\begin{array}{c}\text { Mean } \\
\text { SEM } \\
\text { Month } 5\end{array}$ & $\begin{array}{r}29.6(7) \\
\pm 1.7\end{array}$ & $\begin{array}{l}22.3(7) \\
\pm 1.8\end{array}$ \\
\hline $\begin{array}{l}\text { Mean } \\
\text { SEM }\end{array}$ & $\begin{array}{r}18.5(4) \\
\pm 2.2\end{array}$ & $\begin{array}{r}14.5(4) \\
\pm 0.5\end{array}$ & $\begin{array}{l}\text { Mean } \\
\text { SEM }\end{array}$ & $\begin{array}{r}25.5(4) \\
\pm 1.9\end{array}$ & $\begin{array}{l}16 \\
\pm 0.9\end{array}$ \\
\hline
\end{tabular}

* The number of the determinations on which each mean is based appears in parentheses. SEM = standard error of the mean.

same proportionate rise in the other lipids determined. Total phospholipids, for example, showed a 4- to 5-fold increase and the cholesterolphospholipid ratio was thereby radically increased. Associated with this increase in total phospholipids there was a considerable rise in ethanolamine and serine phosphatides. On the other hand, there was a sharp and consistent fall in the percentage of cholesterol esters in the experimental group.

Coagulation results. The average thromboplastin generation curves of the control and the experimental groups at the end of the first month of the experiment appear in Figure 5. The experimental group showed a more rapid evolution as well as a greater yield of thromboplastin. After an incubation period of 5 minutes, the differences were statistically significant at the 1 per cent level. Similar trends were found in later months. The average monthly results of Quick prothrombin and Stypven times appear in Table V. All the monthly results show a significantly shorter Quick prothrombin time in the experimental as compared with the control group. Since trends were similar for every month, statistical study was done on the pooled results, and the differences were significant at the 1 per cent level. Differences in the Quick prothrombin time of the control group from month to month were due to variation in different batches of thrombo-

TABLE VI

Mean of the clotting times of the prothrombin, factor $V$, and combined factors VII and $X$ determinations expressed as percentage of normal *

\begin{tabular}{|c|c|c|c|c|c|c|}
\hline & \multicolumn{2}{|c|}{ Prothrombin } & \multicolumn{2}{|c|}{ Factor V } & \multicolumn{2}{|c|}{ Factors VII and $\mathrm{X}$} \\
\hline & $\begin{array}{c}\text { Control } \\
\text { group }\end{array}$ & $\begin{array}{l}\text { Exp. } \\
\text { group }\end{array}$ & $\begin{array}{l}\text { Control } \\
\text { group }\end{array}$ & $\begin{array}{c}\text { Exp. } \\
\text { group }\end{array}$ & $\begin{array}{c}\text { Control } \\
\text { group }\end{array}$ & $\begin{array}{l}\text { Exp. } \\
\text { group }\end{array}$ \\
\hline \multicolumn{7}{|l|}{ Month 1} \\
\hline $\begin{array}{l}\text { Mean } \\
\text { SEM }\end{array}$ & $\begin{array}{l}99(10) \\
\pm 8.1\end{array}$ & $\begin{array}{l}135(10) \\
\pm 13.2\end{array}$ & $\begin{array}{l}108(8) \\
\pm 5.5\end{array}$ & $\begin{array}{l}149(8) \\
\pm 18.1\end{array}$ & $\begin{array}{l}95(9) \\
\pm 3.8\end{array}$ & $\begin{array}{l}154(9) \\
\pm 18.2\end{array}$ \\
\hline $\begin{array}{l}\text { Month } 2 \\
\text { Mean } \\
\text { SEM }\end{array}$ & $\begin{array}{l}110(5) \\
\pm 11.6\end{array}$ & $\begin{array}{l}120(5) \\
\pm 5.8\end{array}$ & $\begin{array}{l}108(6) \\
\pm 5.1\end{array}$ & $\begin{array}{l}116(6) \\
\pm 10\end{array}$ & $\begin{array}{l}101(5) \\
\pm 2.1\end{array}$ & $\begin{array}{l}175(5) \\
\pm 21\end{array}$ \\
\hline $\begin{array}{c}\text { Month } 3 \\
\text { Mean } \\
\text { SEM } \\
\text { Month 5 }\end{array}$ & $\begin{array}{l}89.2(6) \\
\pm 4.3\end{array}$ & $\begin{array}{l}109(6) \\
\pm 2.9\end{array}$ & $\begin{array}{l}128(7) \\
\pm 7.4\end{array}$ & $\begin{array}{l}133(7) \\
\pm 11.3\end{array}$ & $\begin{array}{l}92(7) \\
\pm 2.8\end{array}$ & $\begin{array}{l}190(7) \\
\pm 16.5\end{array}$ \\
\hline $\begin{array}{l}\text { Month J } \\
\text { Mean } \\
\text { SEM }\end{array}$ & $\begin{array}{l}92(4) \\
\pm 7.4\end{array}$ & $\begin{array}{l}129(4) \\
\pm 13.5\end{array}$ & $\begin{array}{l}127(4) \\
\pm 4.1\end{array}$ & $\begin{array}{l}108(4) \\
\pm 17.1\end{array}$ & $\begin{array}{l}96(4) \\
\pm 4.8\end{array}$ & $\begin{array}{l}179(4) \\
\pm 11.6\end{array}$ \\
\hline
\end{tabular}

* The number of determinations on which each mean is based appears in parentheses. $\mathrm{SEM}=$ standard error of the mean. 


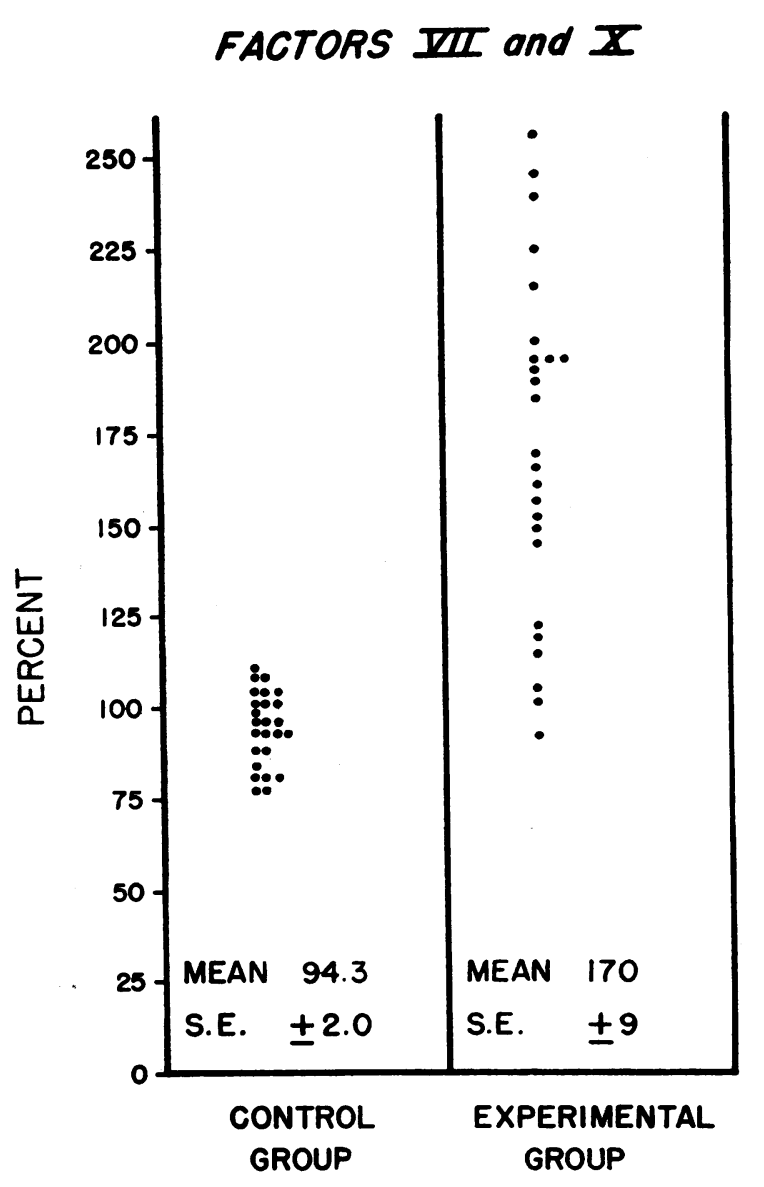

Fig. 6. SCATtergram of the determination OF COMBINED FACTORS VII AND $X$ IN THE CONTROL AND EXPERIMENTAL GROUPS. SE = standard error of the mean.

plastin reagent used. At each monthly interval, however, the same batch of thromboplastin was used in both the control and the experimental groups. Stypven times were consistently and markedly shorter in the diet group. The differences of the pooled results were significant at the 0.1 per cent level.

Quick prothrombin time is an over-all measure for the activity of five specific coagulation factors -namely, fibrinogen, factors V, VII, X, and prothrombin. Therefore, a significantly shorter Quick prothrombin time in the experimental group indicated an increase in the activity of any one or any combination of these factors. The mean results of the determination of these factors appear in Table VI. A prothrombin determination test indicated a significant increase in the content of this factor in the experimental as compared with the control group. The differences of the pooled results were significant at the 1 per cent level. Factor V activity in the experimental group was significantly increased at the 5 per cent level only in the first month. Thereafter the differences were not statistically significant in respect to this test. Combined factors VII and X activity showed a marked increase in the experimental group for the results of every month. The differences of the pooled results were significant at the 0.1 per cent level. In 10 determinations of. factor $\mathrm{X}$, no significant differences were found between the two groups. It therefore appears that the marked differences in the results of the combined factors VII and X between the two groups are due to factor VII itself. A scattergram of the pooled results of factors VII and X appears in Figure 6 and clearly indicates the separation of the experimental group from the control group with respect to this test. Since there were no significant differences between the two groups in respect to factor $\mathrm{X}$ and since the differences with respect to factor $\mathrm{V}$ were significant only in the first month, the increased thromboplastin generation in the experimental group was presumably due to an increase in one or more of the following factors, VIII, IX, XI, and XII. These factors were not measured separately. Serial plasma fibrinogen determinations were not done on this set of animals, but in another group of animals on the diet for 2 months, average plasma fibrinogen was increased from a level of $180 \mathrm{mg}$ per $100 \mathrm{ml}$ in 10 control animals to $258 \mathrm{mg}$ per $100 \mathrm{ml}$ in 10 animals on the diet.

The average results of the streptokinase-induced fibrinolysis and platelet counts are shown in Table VII. The streptokinase-induced fibrinolysis was generally longer in the experimental group. The differences of the pooled results were significant at the 0.1 per cent level. The blood platelet count in the experimental group showed no significant change from month to month, remaining around 700,000 per $\mathrm{mm}^{3}$. In the control group, on the other hand, the platelet count rose from a level of around 700,000 per $\mathrm{mm}^{3}$ in the first month to over $1,000,000$ in later months. The significance of this rise in the platelet count in the control group is not clear. 
TABLE VII

Mean of the streptokinase-induced fibrinolysis times and blood platelet counts *

\begin{tabular}{|c|c|c|c|c|c|}
\hline & \multicolumn{2}{|c|}{$\begin{array}{l}\text { Streptokinase-induced } \\
\text { fibrinolysis (in seconds) }\end{array}$} & & \multicolumn{2}{|c|}{$\begin{array}{l}\text { Platelet counts } \\
\left(\text { per } \mathrm{mm}^{3}\right)\end{array}$} \\
\hline & $\begin{array}{l}\text { Control } \\
\text { group }\end{array}$ & $\underset{\text { group }}{\text { Exp. }}$ & & $\begin{array}{c}\text { Control } \\
\text { group }\end{array}$ & $\begin{array}{c}\text { Exp. } \\
\text { group }\end{array}$ \\
\hline $\begin{array}{c}\text { Month } 2 \\
\text { Mean } \\
\text { SEM }\end{array}$ & $\begin{array}{l}101.4(6) \\
\pm 4.4\end{array}$ & $\begin{array}{l}157.3(6) \\
\pm 9.6\end{array}$ & $\begin{array}{l}\text { Month } 1 \\
\text { Mean } \\
\text { SEM }\end{array}$ & $\begin{array}{l}737,830(9) \\
\pm 41,500\end{array}$ & $\begin{array}{l}673,440(9) \\
\pm 46,070\end{array}$ \\
\hline $\begin{array}{l}\text { Mean } \\
\text { SEM }\end{array}$ & $\begin{array}{l}141.6(6) \\
\pm 6.1\end{array}$ & $\begin{array}{l}238.5(6) \\
\pm 24.8\end{array}$ & $\begin{array}{l}\text { Mean } \\
\text { SEM }\end{array}$ & $\begin{array}{l}911,250(8) \\
\pm 56,500\end{array}$ & $\begin{array}{l}784,870(8) \\
\pm 33,800\end{array}$ \\
\hline $\begin{array}{c}\text { Month } 5 \\
\text { Mean } \\
\text { SEM }\end{array}$ & $\begin{array}{l}158(4) \\
\pm 7.4\end{array}$ & $\begin{array}{l}201.3(4) \\
\pm 27.2\end{array}$ & $\begin{array}{c}\text { Month } 3 \\
\text { Mean } \\
\text { SEM }\end{array}$ & $\begin{array}{l}1,059,500(7) \\
\pm 31,100\end{array}$ & $\begin{array}{l}714,570(7) \\
\pm 54,400\end{array}$ \\
\hline
\end{tabular}

* The number of determinations on which each mean is based appears in parentheses. SEM = standard error of the mean.

It is clear from the data that the changes in blood coagulation and fibrinolysis were already established at the time of the first blood studies. They cannot, therefore, be attributed to the effect of bleeding on the animals or to the anemia that developed in the animals of the experimental group later in the course of the experiment. Further observations suggest that these changes in blood coagulation and fibrinolysis are essentially established by the end of the second week on the diet and therefore long precede the development of detectable vascular lesions.

\section{DISCUSSION}

Our pathological studies in part confirmed the work of Hartroft, O'Neal and Thomas $(4,5)$ and Gresham and Howard (6) insofar as we did find myocardial infarcts as well as large thrombus-like masses in the cardiac chambers and great vessels. We were not convinced, however, that the masses and the infarcts occurred in a pathogenetic sequence. We found definite lesions in the walls of coronary arteries, but a clear-cut pathogenetic relationship between the vascular lesions and the myocardial infarcts could not be ascertained. Thus, the significance of some of the pathological findings is yet to be determined. We did form the opinion, however, that the experimental-group rats, at least in the terminal stage, had an increased tendency to thrombosis. Furthermore, it should be emphasized that regardless of the exact nature of the thrombus-like masses, they were not seen in any animal in the control group.
The effect of diet-induced lipemia on blood coagulation and fibrinolysis has been a subject of much interest in recent years. The only test of blood coagulation that is generally accepted to be accelerated by lipemia is the Stypven test, which is the clotting time of plasma in the presence of Russell viper venom (21). This venom, however, is known to act as a powerful substitute for thromboplastin and factor VII in the presence of certain lipids (22). Thus, a shortening of the Stypven time in diet-induced lipemia need not indicate increased coagulative activity of the blood (23), and since all the other coagulation tests in the past have shown equivocal results $(23,24)$, the whole subject of the relationship between diet-induced lipemia and coagulation changes in vitro has been open to question. Blood coagulation results in diet-induced lipemia have been generally based on studies of blood after a single fatty meal (23). Few investigations of blood coagulation have been reported after prolonged high fat feeding, although in studies of the pathogenesis of arterial disease this may be more pertinent. After a single fatty meal there is a relatively slight increase in the level of some blood lipids, and furthermore the lipid pattern developed is different from the one obtained after prolonged high fat feeding. For example, throughout the digestion of a single fatty meal the level of cholesterol and phospholipids in the blood remains unchanged (24). We started from the premise that coagulation methods usually employed might not have been sufficiently refined to detect minor changes under these circumstances. 
Yet, such minor changes, acting as they would over a number of years, might alter the coagulation-fibrinolysis balance to the point of biological significance. Therefore, it occurred to us that gross elevations of blood lipids that are induced in the course of these experiments over a long period may more likely produce unequivocal changes in blood coagulation. Our results indicate that such, indeed, is the case. We have found associated with gross diet-induced lipemia a significant and unequivocal increase in the coagulative activity of the blood as indicated by a number of coagulation tests-namely, thromboplastin generation test, Quick prothrombin time, Stypven time, and determinations of prothrombin, fibrinogen, and factor VII. To our knowledge, with the exception of the Stypven test, such consistent and unequivocal changes in these tests has not been previously demonstrated. In the presence of liver damage in the experimental group, this increase in coagulation factors such as prothrombin and factor VII, both of which are formed in the liver, is surprising. It may be countered that under these conditions such increases may be attributable to the effect of some dietary ingredient other than the lipemia-inducing ones, such as the vitamin mixture. This, however, is not likely, since in another group of animals given an identical diet, including 2 per cent vitamin mixture and 40 per cent butter, but without the lipemia-inducing cholesterol, sodium cholate, and propylthiouracil, we found no significant changes in blood coagulation or lipid studies (25). The lack of increase in coagulation factors in this group was all the more notable, since the rats showed no pathological lesions in the liver after 6 months on this diet. Indeed, apart from gross obesity there were no remarkable findings at autopsy of these rats and in particular they were free of cardiovascular-renal lesions.

A lower level of streptokinase-induced fibrinolysis was found in the experimental group, as compared with the control group. This result confirms the findings of Nitzberg, Peyman, Goldstein and Proger (24) and Tillman, O'Neal, Thomas and Hixon (26). It should be pointed out, however, that this test is performed under highly artificial conditions and its significance is not entirely clear.
These changes in blood coagulation and fibrinolysis accompanied a marked increase in the level of cholesterol, total fatty acids, total phospholipids including ethanolamine phosphatide and serine phosphatide, and a sharp decrease in percentage of cholesterol esters. The data available do not indicate which one of these lipid determinations best correlates with the observed changes in blood coagulation and fibrinolysis. It is recognized that any comment made in respect to these studies should be considered in the light of the severe limitations imposed by the nature of the experiment-namely, the extreme diet given, the very high levels of blood fats produced, and the possible different interpretations of the pathological lesions induced.

It has been rightly argued (21) that since the relationship between coagulation changes in vitro and the mechanism of thrombosis in vivo is not clear, it would not be possible to decide whether or not the part played by fats in coagulation changes in vitro is relevant to the mechanism of thrombosis in vivo. In our studies the three parameters, high blood fats, coagulation changes in vitro, and a tendency to thrombosis in vivo, seemed to be associated. Yet, though a tentative association among these parameters can be assumed, a cause-and-effect relationship is far from clear.

\section{SUMMARY AND CONCLUSIONS}

In a group of rats given a diet high in cholesterol, sodium cholate, propylthiouracil, and butter, we found:

1) Gross changes in the blood lipids: a) marked increase in total cholesterol, total fatty acids, total phospholipids including ethanolamine phosphatide and serine phosphatide, and a radical rise in cholesterol-phospholipid ratio; and b) sharp fall in percentage of cholesterol esters.

2) Changes in blood coagulation and fibrinolysis favoring thrombosis as indicated by: a) shortening of the clotting time of modified thromboplastin generation, Quick prothrombin time, and Stypven time, and increase in prothrombin, fibrinogen and factor VII ; and b) prolongation of streptokinase-induced fibrinolysis.

3) Definite cardiovascular-renal lesions: a) atheromatous lesions in blood vessels and cardiac 
valves; b) myocardial and renal infarcts; and c) thrombus-like masses in cardiac chambers, great vessels and, rarely, coronary arteries. No clear cause-and-effect relationship was found among these three groups of lesions.

\section{ACKNOWLEDGMENT}

Grateful appreciation is expressed for the expert technical assistance of Miss Betty Busiek.

\section{REFERENCES}

1. Wissler, R. W., Eilert, M. L., Schroeder, M. A., and Cohen, L. Production of lipomatous and atheromatous arterial lesions in the albino rat. Arch. Path. (Chicago) 1954, 57, 333.

2. Fillios, L. C., Andrus, S. B., Mann, G. V., and Stare, F. J. Experimental production of gross atherosclerosis in the rat. J. exp. Med. 1956, 104, 539.

3. Wilgram, G. F. Experimental atherosclerosis and cardiac infarcts in rats. J. exp. Med. 1959, 109, 293.

4. Hartroft, W. S., O'Neal, R. M., and Thomas, W. A. Pathogenesis of atherosclerosis and myocardial infarction. Fed. Proc. 1959, 18, suppl. 3, 36.

5. Thomas, W. A., and Hartroft, W. S. Myocardial infarction in rats fed diets containing high fat, cholesterol, thiouracil, and sodium cholate. Circulation 1959, 19, 65.

6. Gresham, G. A., and Howard, A. N. The independent production of atherosclerosis and thrombosis in the rat. Brit. J. exp. Path. 1960, 41, 395.

7. Alexander, B. Estimation of plasma prothrombin by the one-stage method in The Coagulation of Blood, L. M. Tocantins, Ed. New York, Grune \& Stratton, 1955 , p. 89 .

8. Goldstein, R., Le Belloc'h, A., Alexander, B., and Zonderman, E. Preparation and properties of prothrombin. J. biol. Chem. 1959, 234, 2857.

9. Alexander, B. Determination of Spca (convertin, factor VII) in The Coagulation of Blood, L. M. Tocantins, Ed. New York, Grune \& Stratton, 1955, p. 141.

10. Bachmann, F., Duckert, F., and Koller, F. The Stuart-Prower factor assay and its clinical significance. Thromb. Diath. haemor. 1958, 2, 24.
11. Hicks, N. D., and Pitney, W. R. A rapid screening test for disorders of thromboplastin generation. Brit. J. Haemat. 1957, 3, 227.

12. Loomis, E. C. Estimation of fibrinolysin activity of human plasma or serum in The Coagulation of Blood, L. M. Tocantins, Ed. New York, Grune \& Stratton, 1955, p. 163.

13. Scott, R. F., and Thomas, W. A. Methods for comparing effects of various fats on fibrinolysis. Proc. Soc. exp. Biol. (N. Y.) 1957, 96, 24.

14. Brecher, G., and Cronkite, E. P. Morphology and enumeration of human blood platelets. J. appl. Physiol. 1950, 3, 365.

15. Holburn, R. R. Estimation of fibrinogen in small samples of plasma (method of Ratnoff and Menzie) in The Coagulation of Blood, L. M. Tocantins, Ed. New York, Grune, \& Stratton, 1955, p. 155.

16. Brownlee, K. A. Industrial Experimentation. London, HM Stationery Office, 1957, p. 34.

17. Schoenheimer, R., and Sperry, W. M. A micromethod for the determination of free and combined cholesterol. J. biol. Chem. 1934, 106, 745.

18. Fiske, C. H., and Subbarow, Y. The colorimetric determination of phosphorus. J. biol. Chem. 1925, 66, 375.

19. Stoddard, J. L., and Drury, P. E. A titration method for blood fat. J. biol. Chem. 1929, 84, 741.

20. Axelrod, J., Reichenthal, J., and Brodie, B. B. The direct determination of phosphatidyl ethanolamine and phosphatidyl serine in plasma and red blood cells. J. biol. Chem. 1953, 204, 903.

21. Poole, J. C. F. Fats and blood coagulation. Brit. med. Bull. 1958, 14, 253.

22. MacFarlane, R. G. Blood coagulation, with particular reference to early stages. Physiol. Rev. 1956, 36, 479.

23. O'Brien, J. R. Dietary fat and coronary disease. Brit. med. J. 1957, 2, 297.

24. Nitzberg, S. I., Peyman, M. A., Goldstein, R., and Proger, S. Studies of blood coagulation and fibrinolysis in patients with idiopathic hyperlipemia and primary hypercholesterolemia before and after a fatty meal. Circulation 1959, 19, 676.

25. Naimi, S., Goldstein, R., Nothman, M. M., Wilgram, G. F., and Proger, S. Unpublished observations.

26. Tillman, R. L., O'Neal, R. M., Thomas, W. A., and Hixon, B. B. Butter, corn oil and fibrinolysis in rats. Circulat. Res. 1960, 8, 423. 